\title{
Article
}

\author{
Doi 10.5943/sif/6/1/32
}

\section{Ectomycorrhizal fungi associated with Pinus gerardiana in Kinnaur district of Himachal Pradesh, India}

\author{
Tapwal A*, Kapoor KS, Thakur Y and Kumar A
}

Himalayan Forest Research Institute, Shimla-171013, India

Tapwal A, Kapoor KS, Thakur Y, Kumar A 2021 - Ectomycorrhizal fungi associated with Pinus gerardiana in Kinnaur district of Himachal Pradesh, India. Studies in Fungi 6(1), 425-436, Doi $10.5943 /$ sif/6/1/32

\begin{abstract}
Investigations on the diversity of ectomycorrhizal macrofungi associated with Pinus gerardiana in Kinnaur district of Himachal Pradesh revealed the associations of 22 ectomycorrhizal fungi belonging to 12 genera in 11 families. The dominant genus was Geastrum (4 species), followed by Russula and Suillus (3 species each); Boletus, Ramaria and Scleroderma (2 species each) and rest of the genera were represented by one species each. Among these, Scleroderma polyrhizum had the highest frequency of occurrence and was recorded in most of the sites. Maximum diversity was recorded beyond $2500 \mathrm{~m}$ above mean sea level. Morpho-anatomical study of mycorrhizal roots revealed typical ectomycorrhizal association exhibiting well-developed mantle and hartig net.
\end{abstract}

Keywords - Chilgoza Pine - Ectomycorrhiza - Kinnaur - Macro-fungi

\section{Introduction}

Pinus gerardiana Wall. ex D. Don is an important conifer plant species of North-West Himalaya and is restricted in distribution to the mountains of Eastern Afghanistan, Pakistan and North-Western Himalaya of India. In Himachal Pradesh, it is mainly distributed in Kinnaur district and in Pangi and Bharmour valleys of Chamba district (Kapoor et al. 2003). It occupies an altitudinal range of $1,600 \mathrm{~m}$ to $3,000 \mathrm{~m}$ above $\mathrm{msl}$ in dry inner valleys of North-West Himalaya. The seeds (chilgoza/neoza) are edible and rich in proteins, carbohydrates, fibers, minerals and highquality oil. The oil is free of cholesterol and constitutes a rich source of fatty acids like stearic acid, linoleic acid, oelic acid, arachidic acid and palmitic acid (Thakur et al. 2015). The chilgoza fetches very high price in the open market and plays an important role in socio-economic uplift of the people in tribal areas of Himachal Pradesh and Union territory of Jammu and Kashmir (Sehgal \& Khosla 1986, Malik et al. 2012). Forest provides habitat for diverse macrofungi and their composition may vary markedly in different sites. Variety of macrofungi are growing in the forests of Kinnaur and local relish on them. Morels are contributing substantially in the income to inhabitants of fringe forests. Chauhan et al. (2014) and Parmar (2016) made efforts to explore the diversity of macrofungi from Kinnaur district but their emphasis was not on mycorrhizal association.

Mycorrhizae are known to play an important role in the establishment of seedlings of host plant by facilitating nutrient and water uptake and by enhancing host tolerance in stressful conditions (Brundrett 2002). Kumar (1989) identified three mycorrhizal types: white creamish, yellowish brown and black types and Sehgal \& Sagar (2017) have identified four types of 
ectomycorrhizae in the roots of $P$. gerardiana. But the dark brown and dark redish types recognized by them may represent two developmental stages of the same. About 6,000 plant species are known to enter into ectomycorrhizal association with 20,000 fungal taxa (van der Heijden et al. 2015). The present study give a preliminary account of ectomycorrhizal fungi associated with $P$. gerardiana.

\section{Materials \& methods}

\section{Study area}

The study was conducted in the Pinus gerardiana forests of Kinnaur district, Himachal Pradesh (Fig. 1). The area has mountainous topography with steep valleys, glaciated mountains, which experience extremes in temperature coupled with excessive dryness. Most of the area of district has a temperate climate with long winters. The upper part of the district falls in the rain shadow area and receives heavy to moderate snowfall. This area has sparse vegetation comprising hardy grasses, dry alpine scrub and dwarf juniper scrub. While the vegetation in lower part of district comprises of trees like pine, oak, chestnut, birch, deodar, fir, grasses and shrubs. The transition area between these two climatic and vegetation zones constitutes the natural forests of Pinus gerardiana.

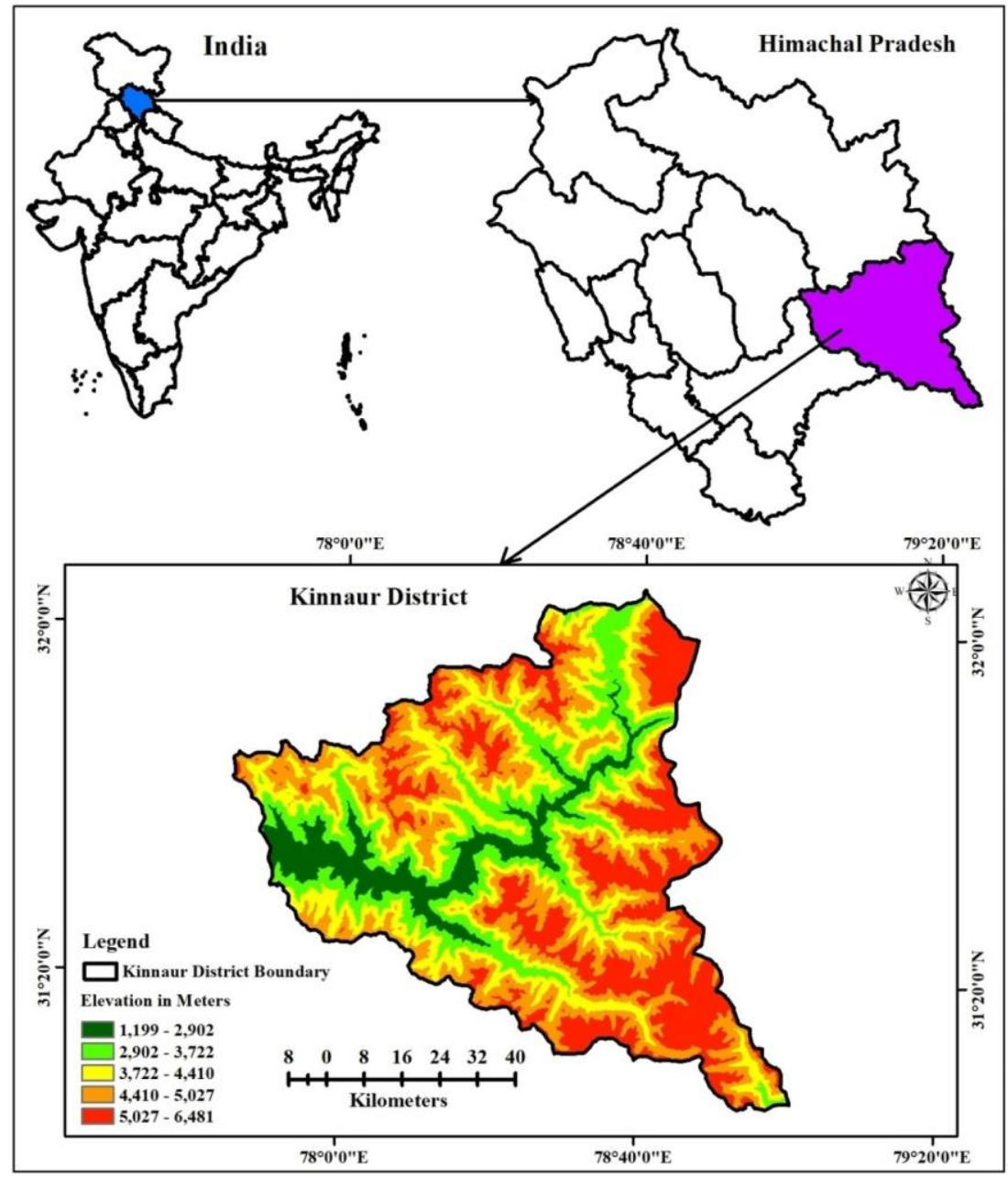

Fig. 1 - Study area.

\section{Survey and collection of ectomycorrhizal fungi}

Periodic field visits were carried out in the forests of Pinus gerardiana in rainy season from July to September during 2016-18. The GPS coordinates of the study sites were recorded. The 
macrofungi/mushrooms growing in the vicinity of $P$. gerardiana and mycorrhizal roots of host plant were collected. The macrofungi were observed visually for their connection with the roots for confirming their mycorrhizal nature. Sporophores of mycorrhizal fungus were removed carefully digging the soil with sharp knife and collected in waxed paper bags along with mycorrhizal roots. The specimens which were closely associated with the roots were collected and assigned collection numbers. The specimens were dried in the sun and also at $40^{\circ} \mathrm{C}$ in oven for later reference. The specimens were also preserved wet in Alcohol Formalin (Formaline 40\% $=25 \mathrm{ml}$, Alcohol 95\% $150 \mathrm{ml}$, Water $100 \mathrm{ml}$ ) in screw capped glass jars following Hawksworth et al. (1983). The specimens have been deposited in the fungarium of Forest Protection Division, Himalayan Forest Research Institute, Shimla. Faces of fungi numbers were registered as mentioned in Jayasiri et al. (2015).

\section{Identification of ectomycorrhizal fungi}

Macroscopic details, size, shape and colour of cap, stipe of the carpophores, colour change on bruising, odour of the specimen, attachment to root, and presence of rhizomorphs noted in fresh fruiting body. The characters of spores like colour, size, shape, ornamentations etc. were recorded. Anatomical detail of the specimens was studied by cutting free hand sections. The details of basidia, cystidia, hymenophoral trama, pileus cuticle, pileus context, stipe cuticle, stipe context and clamp connections were recorded under microscope. The macrofungi were identified on the basis of macro and microscopic characteristics following mushroom dedicated websites and available literature (Purakasthya \& Chandra 1985, Singer 1986, Kirk et al. 2008)

\section{Morphology and anatomy of mycorrhizal roots}

Mycorrhizal roots were preserved in Formaline Acetic Acid (FAA) (Formaldehyde 40\% = 5 $\mathrm{ml}$, Ethyl Alcohol $70 \%=90 \mathrm{ml}$, Acetic Acid = $5 \mathrm{ml}$ ) for 24 hours, then thoroughly rinsed in running water and preserved in $70 \%$ alcohol. Morphological details of mycorrhizal roots like colour, branching pattern, and size were recorded under stereo zoom microscope. For anatomical study, transverse sections of the mycorrhizal roots were cut, temporary mounts were prepared and observed under microscope for colour/thickness/texture of the fungal mantle, extraradical hyphae and Hartig net (Johansen 1940, Zak 1971). The colour of the Hartig net and mantle was observed in unstained sections. To study the cellular details, the sections were stained in lactophenol cotton blue and examined under microscope.

\section{Results}

\section{Ectomycorrhizal fungi associated with $P$. gerardiana}

Surveys were conducted in thirty-four sites in sixteen forests of $P$. gerardiana in rainy season. The ectomycorrhizal macrofungi growing in the vicinity of $P$. gerardiana were collected and GPS coordinates of collection site were recorded (Fig. 2). The brief description of ectomycorrhizal fungi is given below:

Amanita pantherina - Cap 4-11cm in diameter, grey-brown finely striate margin, pure white dotted remains of universal veil on cap surface. Stipe $5-14 \mathrm{~cm}$ long, subcylindric, pure white bearing a hanging ring and volva at the base. Gills were free, close to crowded, white and turn

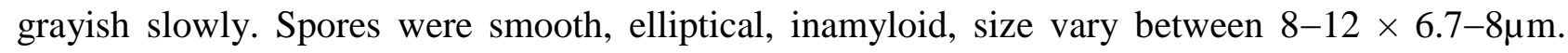
Specimen ID: HFRI/M/5145; FoF 04998.

Boletus bicolor - Cap 5-6 cm in diameter, brick red to reddish brown in colour, convex to flat and sticky. Stipe is fleshy, $3-4 \mathrm{~cm}$, red to purplish red, tapering toward top. The tubes are pale yellow in colour and slowly brushing blue. Spores are $10 \times 6 \mu \mathrm{m}$, sub-fusiform, smooth. Specimen ID: HFRI/M/5109; FoF 10102. 
Boletus edulis - Cap 7-22cm in diameter, yellowish brown to reddish brown, convex to flat in shape and sticky. Stipe is fleshy, 7-18 cm long, thick and bulge out in middle. The tubes are 1 to 2 $\mathrm{cm}$ deep, and whitish in colour when young, but on maturity turn to greenish-yellow. The spores are $6 \times 16 \mu \mathrm{m}$, elliptical to spindle shaped. Specimen ID: HFRI/M/5110; FoF 05350.

Geastrum floriforme - Fruiting body subglobose, 3-5 × 1-2.5cm. Exoporidium splitting into 4-9 pointed rays, look like petals of daisy, saccate, hygroscopic. The spore sac is $1-2 \mathrm{~cm}$, oblate

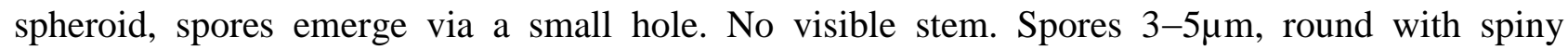
ornamentation. Specimen ID: HFRI/M/5115; FoF 10103.

Geastrum corollinum - Expanded basidiomes, $2.5-5.0 \times 1.5-2.0 \mathrm{~cm}$, splitting into 8-12 equal, slender, rigid, hygrometric rays, endoperidium sessile, $0.5-1.5 \mathrm{~cm}$ in diameter. Spores $3-5 \mu \mathrm{m}$, round and warted. Specimen ID: HFRI/M/5120; FoF 10104.

Geastrum fimbriatum - Expanded basidiomes 1-1.8 $\times 0.8-1.8 \mathrm{~cm}$. Exoporidium splitting into 4-6 rays, saccate, some evolute, non-hygroscopic. Endoporidial body, 0.7-1.5 × 0.7-1.1cm. Spores 5-8 $\times 5.5-8 \mu \mathrm{m}$ round and spiny. Specimen ID: HFRI/M/5124; FoF 01073.

Geastrum saccatum - Expanded basidiomes 2-3.8 $\times 0.8-1.8 \mathrm{~cm}$. Exoporidium splitting into 5-9 triangular rays, non-hygroscopic. Endoporidial body $1-1.5 \times 0.8-1.2 \mathrm{~cm}$. Spores $3-5 \mu \mathrm{m}$, round and densely spiny. Specimen ID: HFRI/M/5114; FoF 05194.

Hydnellum concrescens - Cap 4-6cm, plane to depressed, margin evenly to irregularly lobed, reddish white to dark brown. Stipe central, $5.3 \times 1.3 \mathrm{~cm}$ attenuating upward and brown. Spines up to $2 \mathrm{~mm}$ long, decurrent, crowded reddish brown. Spores $6.5 \times 4-4.8 \mu \mathrm{m}$, subglobose. Specimen ID: HFRI/M/5122; FoF 10105.

Hygrocybe conica - Cap 1.5-3cm, bright orange, sharply conical initially to broadly conical with a raised centre at maturity, sticky when fresh. Stipe is $3-4.6 \mathrm{~cm}$. Gills sharply attached to stipe, close to sub distant and yellowish. Spores were $7-11.5 \times 4.5-6.5 \mu \mathrm{m}$, smooth. Specimen ID: HFRI/M/5117; FoF 10106.

Lycoperdon pyriforme - Fruiting body $2-5.5 \mathrm{~cm}$, light brown, initially round, inverted pear shaped at maturity, bear spines like structures. Spores 3.6-5.0 $\mu \mathrm{m}$, globose, smooth. Specimen ID: HFRI/M/5144; FoF 05335.

Phallus impudicus - Cap was spike like, $4.5-6.0 \mathrm{~cm}$, reticulate, slimy, perforation at tip. Stipe $18-20 \times 2.5-3.8 \mathrm{~cm}$ and hollow. A sac like volva present at the base. Spores $8.5-9.7 \times 4-4.3 \mu \mathrm{m}$ and smooth. Specimen ID: HFRI/M/5128; FoF 10107.

Ramaria apiculata - Fruiting body $6-10 \mathrm{~cm}$ high and $3-6 \mathrm{~cm}$ wide, tan to cinnamon brown and branching repeatedly branching vertically oriented and elongated, often flattened, smooth. Spores were elliptical, 8.5-10 × 3.5-4 $\mu \mathrm{m}$. Specimen ID: HFRI/M/5137; FoF 10108.

Ramaria stricta - Fruiting body $5-11 \mathrm{~cm}$ high and $1.5-5 \mathrm{~cm}$ wide, repeatedly branched in vertical oriented, elongated, often flattened, smooth, yellowish buff to purplish brown. Spores were 7.5-10.5 × 3.5-5 $\mu \mathrm{m}$ and elliptical. Specimen ID: HFRI/M/5129; FoF 10109.

Russula brevipes - Cap $12 \mathrm{~cm}$, convex with a central depression to vase shaped with inrolled margin, white to creamy coloured. Gills were attached to the stem or running down it slightly, 
crowded and white in colour. Stipe $4 \times 2 \mathrm{~cm}$, white. Spores were 7-10 $\times 5-7 \mu \mathrm{m}$, ellipsoid and warty. Specimen ID: HFRI/M/5131; FoF 05051.

Russula delica - Cap 5-12cm in diameter, milky white to cream coloured, convex, with an inrolled margin. Gills narrow and slightly crowded and decurrent. Stipe was 4-6 cm long. Spores were

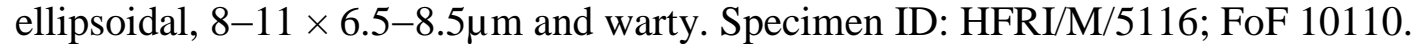

Russula emetica - Cap 4-12cm, brick red to purplish red, convex to flat with an incurved margin, sticky when fresh. Gills were broadly attached to the stem, close and crowded. Stem $3.5-8 \mathrm{~cm}$ long. Spores were ellipsoidal, $8-11 \times 7.5-8.5 \mu \mathrm{m}$ and warty. Specimen ID: HFRI/M/5113; FoF 08943.

Scleroderma hypogaeum - Fruiting body was $2.5-6.2 \mathrm{~cm}$, lobed, brownish colour, finely hairy with white rhizomorph. Spores were round, 15-22.4 $\mu$ m, dense spines. Specimen ID: HFRI/M/5121; FoF 10111.

Scleroderma polyrhizum - Fruiting body was nearly round, $3.5-3.8 \mathrm{~cm}$ in diameter and $4.2 \mathrm{~cm}$ high. Spore mass black to purplish black, hard at first, becoming dark brown and powdery. Spores were round, 7-9.4 $\mu \mathrm{m}$ with fine spines. Specimen ID: HFRI/M/5118; FoF 10112.

Strobilomyces strobilaceus - Cap 3-5 cm, convex to nearly flat, covered with upright, woolly, blackish scales. The tubes were pale grey at to black. Stipe was $5-8 \times 1-1.5 \mathrm{~cm}$ grey and covered

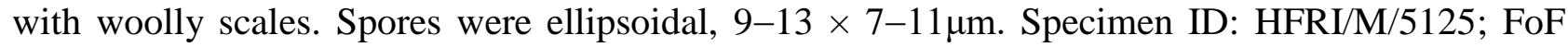
10113.

Suillus brevipes - Cap 3.5-10.0 cm broad, convex, surface smooth, viscid, dull cinnamon-brown coloured. Tubes adnate, decurrent and yellowish-brown coloured. Stipe was straight, dull white to pale-yellowish. Spores 7.2-9 × 3-4.1 $\mu \mathrm{m}$, smooth and elliptical. Specimen ID: HFRI/M/5131; FoF 08946.

Suillus granulates - Cap 5-12cm, convex becoming broadly convex, sticky and smooth, yellowish to dark cinnamon brown. The tubes were shallow and lemon yellow. Stipe with tapering base bearing brownish glandular dots. Spores $7-10 \times 2.6-3.2 \mu \mathrm{m}$ and smooth. Specimen ID: HFRI/M/5112; FoF 10114.

Suillus luteus - Cap $8.2 \mathrm{~cm}$, broadly convex to flat, slimy and shiny, partial veil whitish yellow, often hanging from the margin, cover the pores. Stipe whitish to yellowish towards apex, glandular dots above the ring. Spores $8-10.6 \times 2.8-3.3 \mu \mathrm{m}$, sub-fusiform and smooth. Specimen ID: HFRI/M/5116; FoF 10115.

The macrofungi collected belonged to 22 species, 12 genera in 11 families (Figs 4, 5). The dominant genus was Geastrum (four species), followed by Russula and Suillus (three species each); Boletus, Ramaria and Scleroderma (two species each) and rest of the genera were represented by one species each. Among these, Scleroderma polyrhizum had the highest frequency of occurrence in 29 sites (85.29\%). It was followed by Scleroderma hypogaeum (40.59\%), Lycoperdon pyriforme (61.76\%), Geastrum floriforme and Geastrum saccatum (47.06\%). The minimum frequency of occurrence (2.94\%) was for Amanita pantherina and Phallus impudicus which were recorded at one site only. Among the families Geastraceae was the dominant with four species (18.18\% representation), followed by Boletaceae, Russulaceae and Suillaceae with three species (13.64\% representation) and Gomphaceae and Sclerodermataceae with two species each (9.09\% representation). Rest of families were represented by one species each (4.55\% representation) 
(Fig. 4). Literature survey revealed that, 13 species were edible, seven were inedible and two species had doubtful edibility.

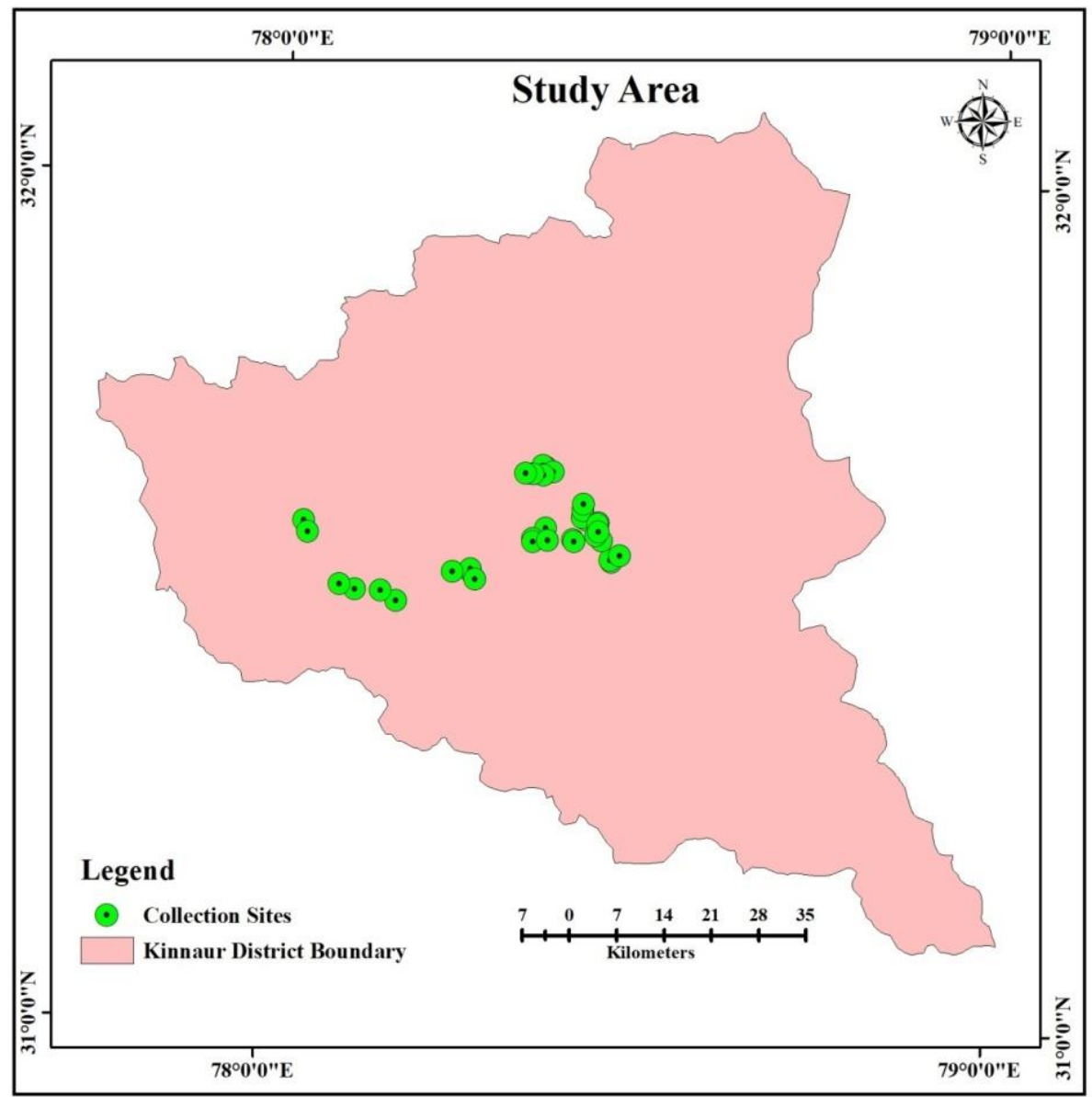

Fig. 2 - Sites surveyed for collection of mycorrhizal fungi.

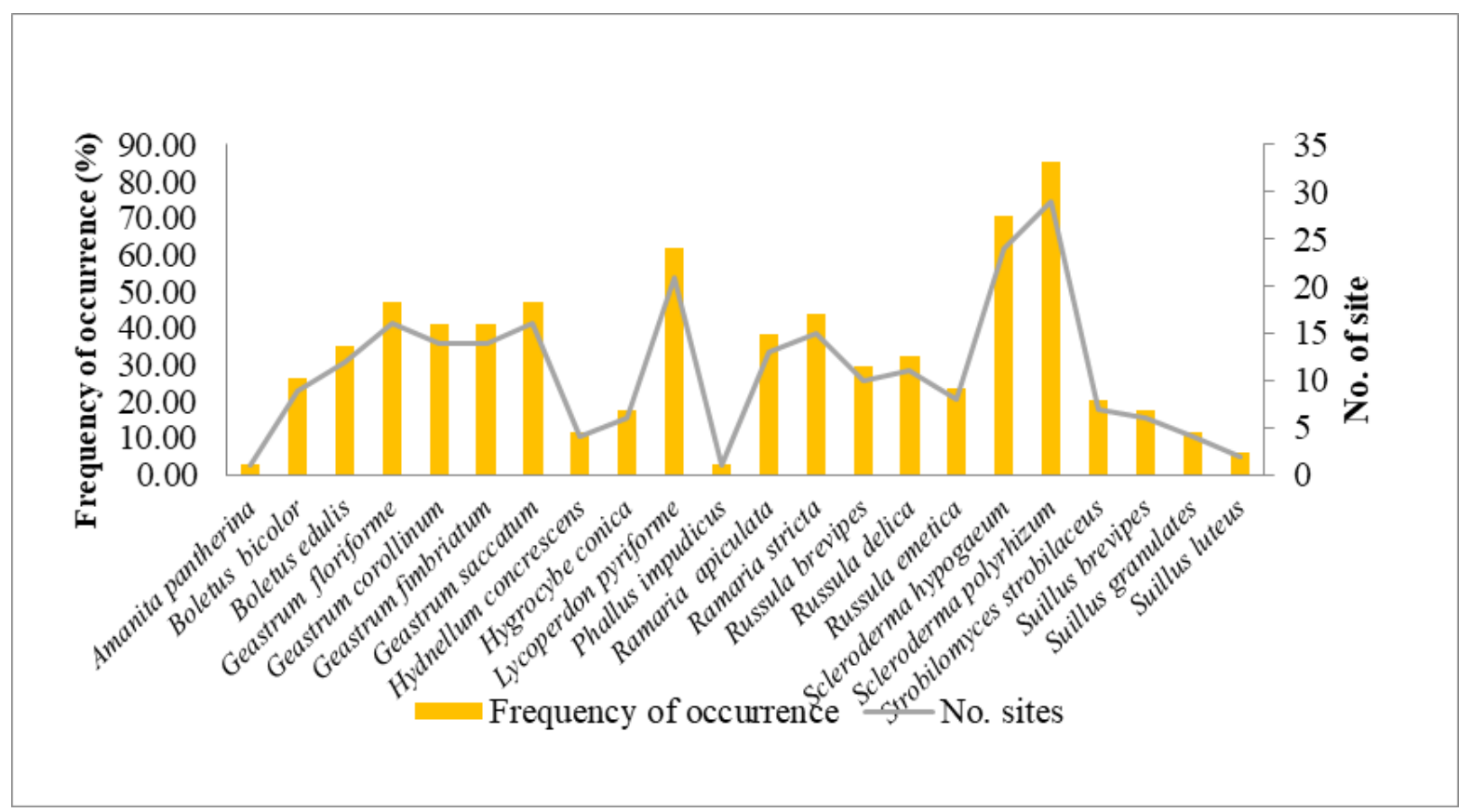

Fig. 3 - Frequency of occurence and no. of sites from which mycorrhizal macrofungi were collected. 


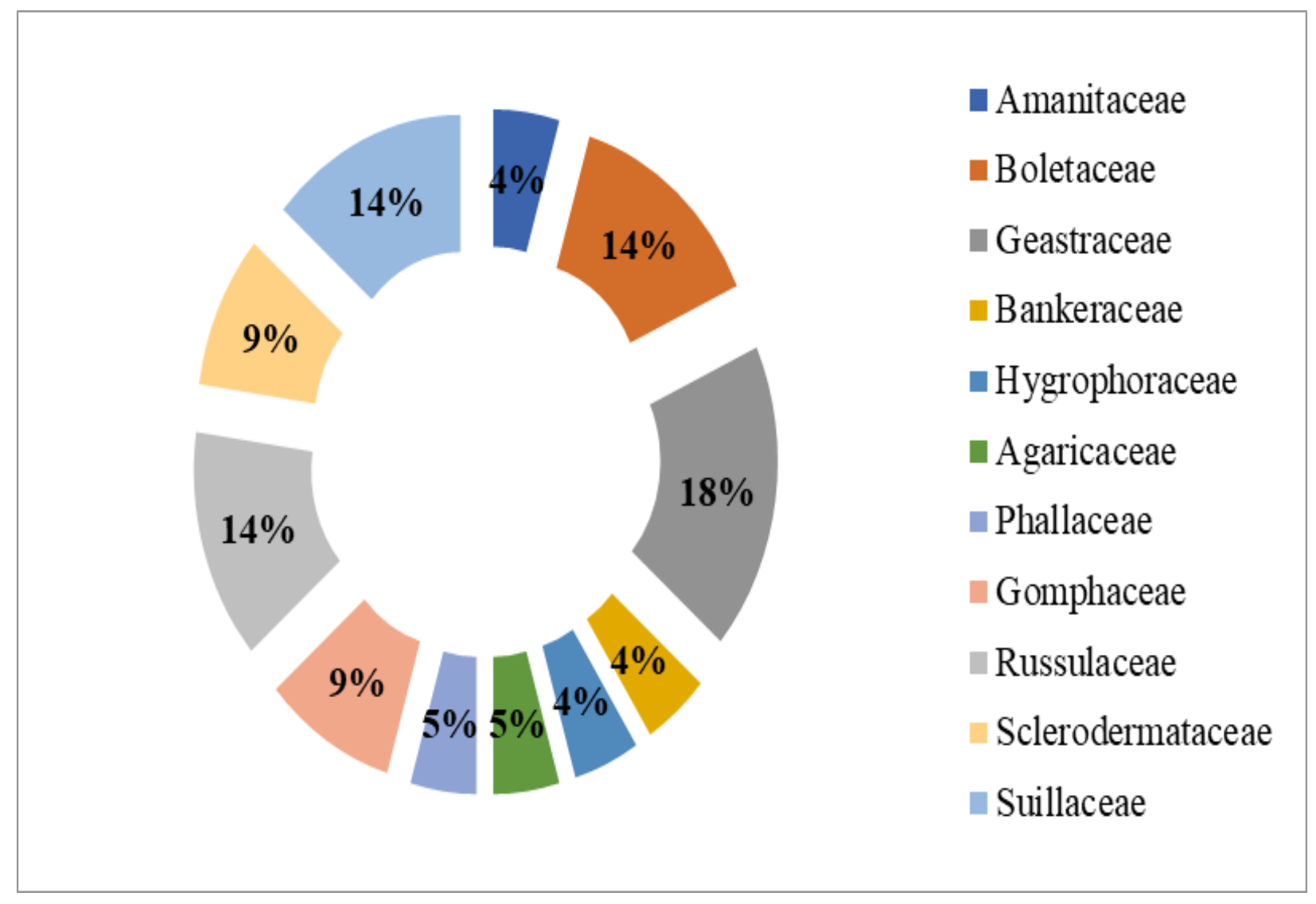

Fig. 4 - Family wise percent representation of ectomycorrhizal fungi.

\section{Distribution of ectomycorrhizal fungi along attitudinal gradient}

Pinus gerardiana grows in a narrow range of altitude varying between $1600-3300 \mathrm{~m}$ amsl. Following Malik et al. (2012) the study area was divided into three zones on the basis of elevation and details are presented in table-1. The study revealed that 9, 12 and 20 mycorrhizal fungi were recorded from zone - I, II and III respectively. Boletus edulis, Geastrum corollinum, G. saccatum, Lycoperdon pyriforme, Ramaria stricta, Russula emetica, Scleroderma polyrhizum were recorded from all three zones. Rest of the species were present in one or two zones. Beside P. gerardiana, other tree species recorded in the study area are Cedrus deodara, Juglans regia, Pinus wallichiana, Prunus armeniaca and Quercus ilex (Table 1).

\section{Host-fungus relationship}

Mycorrhizal roots collected from the study sites were investigated for morphological and anatomical details under stereo zoom microscope (Nikon SMZ1500). Young mycorrhizal roots were light in colour which darkens with age. The ectomycorrhizal roots were generally monopodial/dichotomously branched and sometimes subsequent branching assumes coralloid appearance. Every bifurcation of short root is considered as an ectomycorrhiza. Under low magnification, the mycorrhizal roots appeared with swollen tips, and the root hairs were absent. Each mycorrhizal root was enveloped with fungal sheath and numerous hyphae were radiating from the hyphal sheath. The colour of the mycorrhizal roots varied from light yellow, yellow, light brown to brown. Average diameter of mycorrhizal roots near the base of dichotomy varied from $0.18 \mathrm{~mm}$ to $0.27 \mathrm{~mm}$, whereas at the tips, it varied from $0.07 \mathrm{~mm}$ to $0.15 \mathrm{~mm}$ (Fig. 6).

For anatomical study, transverse sections of mycorrhizal roots were stained in lactophenol cotton blue and temporary mounts were observed under Nikon-E 400 microscope. The roots were enveloped with $8-31 \mu \mathrm{m}$ thick mantle from which numerous fungal hyphae were radiating. The Hartig net formation was recorded in the intercellular spaces of cortical cells in 2-5 layers. The fungal hyphae do not enter into the cortical cells and endodermis. 


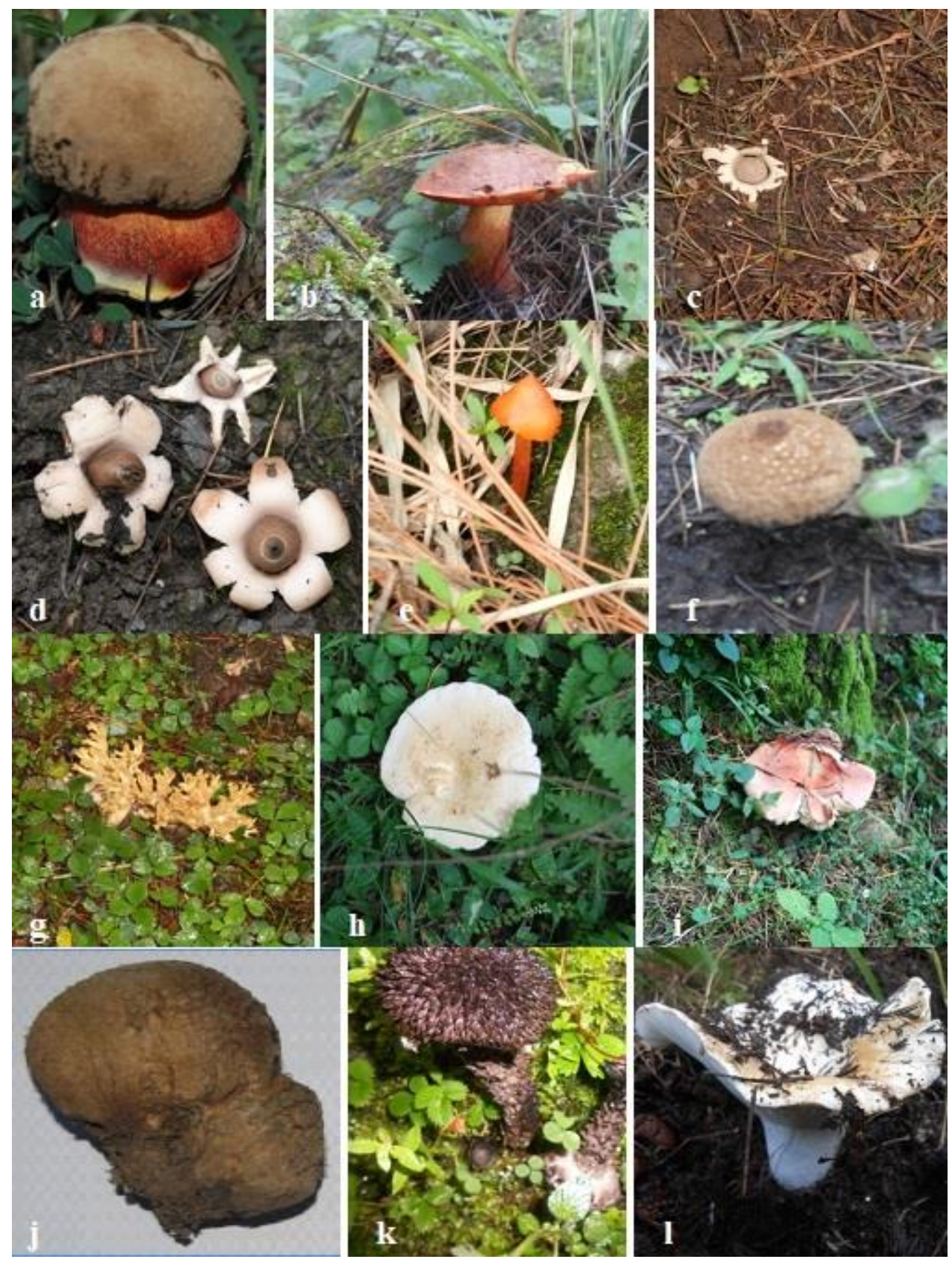

Fig. 5 - a Boletus edulis. b Boletus bicolor. c Geastrum corollinum. d Geastrum saccatum. e Hygrocybe conica. f Lycoperdon pyriforme. g Ramaria apiculata. h Russula delica. i Rusulla emetica. j Scleroderma polyrhizum. k Strobilomyces strobilaceus. 1 Russula brevipes.

Table 1 Distribution of macro fungi across the altitudinal gradient

\begin{tabular}{|c|c|c|c|}
\hline Zone/Elevation & $\begin{array}{l}\text { Sites of } \\
\text { collection }\end{array}$ & Major tree species & Mycorrhizal fungi collected \\
\hline $\begin{array}{l}\text { ZONE 1 } \\
(1700-2100 \mathrm{~m} \\
\text { amsl) }\end{array}$ & $\begin{array}{l}\text { Kilba, Punang, } \\
\text { Tangling, Tapri }\end{array}$ & $\begin{array}{l}\text { Aesculus indica, Cedrus } \\
\text { deodara, Celtis australis, } \\
\text { Juglans regia, Olea } \\
\text { cuspidata, Alnus nitida, } \\
\text { Pinus gerardiana, Pinus } \\
\text { wallichiana, Prunus } \\
\text { armeniaca and Quercus } \\
\text { ilex }\end{array}$ & $\begin{array}{l}\text { Boletus edulis, Geastrum } \\
\text { corollinum, G. saccatum, } \\
\text { Lycoperdon pyriforme, } \\
\text { Ramaria stricta, Russula } \\
\text { emetica, Scleroderma } \\
\text { polyrhizum, Suillus granulates } \\
\text { and Suillus luteus }\end{array}$ \\
\hline
\end{tabular}


Table 1 Continued.

\begin{tabular}{|c|c|c|c|}
\hline Zone/Elevation & $\begin{array}{l}\text { Sites of } \\
\text { collection }\end{array}$ & Major tree species & Mycorrhizal fungi collected \\
\hline $\begin{array}{l}\text { ZONE } 2 \\
(2100-2500 \mathrm{~m} \\
\text { amsl) }\end{array}$ & $\begin{array}{l}\text { Akpa, Jangi, } \\
\text { Kalpa, Skibba }\end{array}$ & $\begin{array}{l}\text { Alnus nitida, Cedrus } \\
\text { deodara, Fraxinus } \\
\text { xanthoxyloides, Juglans } \\
\text { regia, Pinus gerardiana, } \\
\text { Pinus wallichiana, } \\
\text { Populus ciliata, Prunus } \\
\text { armeniaca, Prunus mira } \\
\text { and Quercus ilex }\end{array}$ & $\begin{array}{l}\text { Boletus edulis, Geastrum } \\
\text { corollinum, G. saccatum, } \\
\text { Hydnellum concrescens, } \\
\text { Lycoperdon pyriforme, } \\
\text { Ramaria stricta, Russula } \\
\text { emetica, R. brevipes, } \\
\text { Scleroderma hypogaeum, } \\
\text { Scleroderma polyrhizum, } \\
\text { Suillus brevipes and } \\
\text { S. luteus }\end{array}$ \\
\hline $\begin{array}{l}\text { ZONE } 3 \\
(2500 \mathrm{~m} \text { amsl and } \\
\text { above) }\end{array}$ & $\begin{array}{l}\text { Akpa, Jangi, } \\
\text { Kalpa, Khopka, } \\
\text { Lappo, Lippa, } \\
\text { Moorang, } \\
\text { Ribba, Rispa, } \\
\text { Rowang, } \\
\text { Skibba, Thangi. }\end{array}$ & $\begin{array}{l}\text { Abies pindrow, Betula } \\
\text { utilis, Cedrus deodara, } \\
\text { Fraxinus xanthoxyloides, } \\
\text { Juglans regia, Picea } \\
\text { smithiana, Pinus } \\
\text { gerardiana, Pinus } \\
\text { wallichiana, Prunus } \\
\text { armeniaca, Prunus mira } \\
\text { and Quercus ilex }\end{array}$ & $\begin{array}{l}\text { Amanita pantherina, Boletus } \\
\text { bicolor, Boletus edulis, } \\
\text { Geastrum floriforme, } \\
\text { G. saccatum, G. fimbriatum, } \\
\text { G. corollinum, Hydnellum } \\
\text { concrescens, Hygrocybe } \\
\text { conica, Lycoperdon pyriforme, } \\
\text { Phallus impudicus, Ramaria } \\
\text { apiculata, R. stricta, Russula } \\
\text { delica, } R \text {. emetica, R. brevipes, } \\
\text { Scleroderma hypogaeum, } \\
\text { S. polyrhizum, Strobilomyces } \\
\text { strobilaceus and Suillus } \\
\text { brevipes }\end{array}$ \\
\hline
\end{tabular}
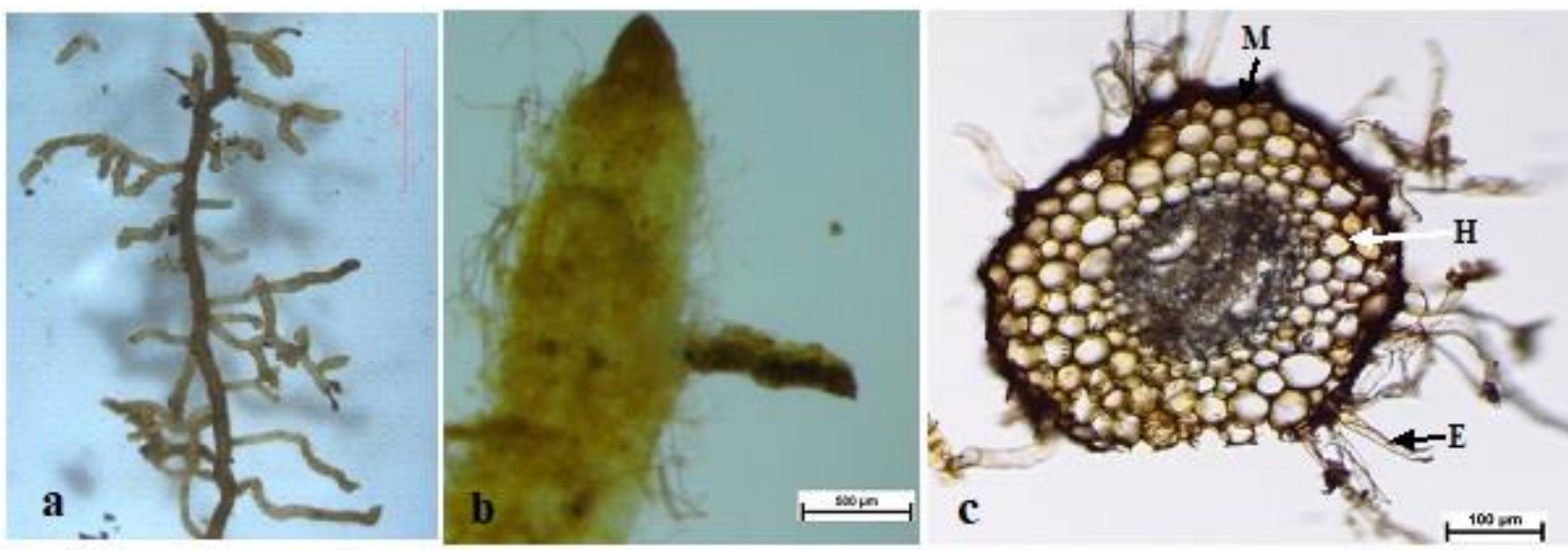

Fig. 6 - a Mycorrhizal roots of Pinus gerardiana. b Closer view of mycorrhizal root. c T.S. of mycorrhizal root showing mantle $(\mathrm{M})$, Hartig net $(\mathrm{H})$ and extramatrical hyphae $(\mathrm{E})$. Scale bars: $\mathrm{a}=$ $1 \mathrm{~mm}, \mathrm{~b}=500 \mu \mathrm{m}, \mathrm{c}=100 \mu \mathrm{m}$.

\section{Discussion}

Pinus gerardiana is ecologically and economically important tree of Kinnaur district. In the present investigation, typical ectomycorrhizal association was observed in the roots of $P$. gerardiana. The mycorrhizal roots were dichotomously branched and colour varied as light yellow, yellow, light brown and brown. Bakshi \& Thaper (1966) reported bifurcate type mycorrhizae in pines, while Lakhanpal \& Chaudhary (1988) observed dichotomous or coralloid type 
ectomycorrhizal roots in P. gerardiana. Lakhanpal \& Kumar (1984) and Kumar (1989) reported creamish white, yellowish brown and black type of mycorrhizae in Pinus gerardiana, while Sehgal \& Sagar (2017) reported one additional type of mycorrhiza.

The ectomycorrhizal roots can be differentiated by the presence of a sheath of fungal hyphae around the root called mantle, Hartig-net- consisting of fungal hyphae that grows between cortical cells and the long radiating hyphae that connect the soil with the fruiting bodies of the fungi (Smith \& Read 1997, Watkinson 2016). According to Peterson et al. (2004) the ectomycorrhizal roots can be recognized through their structural modification viz. dichotomous, coralloid or short monopodial branching pattern that are totally different from non-mycorrhizal roots. The morphological and anatomical structure of ectomycorrhizal roots vary within single plant species due to its association with different fungi (Agerer 1995). Plant-fungus specificity in ectomycorrhizal associations varies from narrow to broad host range fungi (Molina et al. 1992).

Average diameter of mycorrhizal root near the base of dichotomy was recorded in the range of $0.18-0.27 \mathrm{~mm}$ whereas at the tips, it varied from $0.07-0.15 \mathrm{~mm}$. The mantle was $8-31 \mu \mathrm{m}$ thick and Hartig net formation was recorded in intercellular spaces in 2-5 cortical layers. In similar study, Sehgal \& Sagar (2017) also recorded mantle formation in the range of 10-35 $\mu \mathrm{m}$ in the ectomycorrhizal roots of $P$. gerardiana. Kieliszewska-Rokicka et al. (2000) also recorded similar anatomy in the ectomycorrhizal roots of Pinus sylvestris and Fagus sylvatica. The ectomycorrhizal association is characterized by presence of the hyphal sheath or mantle, the Hartig net and the extraradical hyphae (Bücking et al. 2012). Bakshi \& Thapar (1960) observed 27-45 $\mu$ m wide fungal mantle in the natural mycorrhizal roots of blue pine with 10-12 cell layers forming a pseudoparenchymatous sheath.

During field surveys in different seasons, 22 macrofungal species belonging to 12 genera were recorded from different forests in Kinnaur district. The study area has been little explored on the diversity of macrofungi and their possible association with $P$. gerardiana. Kumar (2010) has recorded Amanita ceciliae, Boletus edulis, Lactarius sanguifluus and Suillus sibiricus from P. gerardiana forests. Chauhan et al. (2014) and Parmar (2016) reported twelve and twenty macrofungi respectively from different parts of district Kinnaur. But did not study their mycorrhizal relationship and the collection represent both mycorrhizal as well non-mycorrhizal mushrooms. Ectomycorrhizal fungi are omnipresent in forest ecosystems, especially in temperate regions, forming symbiotic associations with roots of woody plants and help the host in nutrient and water absorption, as well as protection against pathogens, abiotic stresses and heavy metal toxicity etc. Mycorrhizal associations are regulated by the host plant, mycorrhizal fungus, as well as soil conditions and environmental factors (Peterson et al. 2004, Silva et al. 2013, Clasen et al. 2018).

The study of fungal biodiversity has been explored world over (Crous 2006) and it is estimated that about 1.5 million species exists on globe (Hawksworth 2004). About $50 \%$ of them have been characterized (Manoharachary et al. 2005). There are approximately 7000 to 10000 fungal species and 8000 plant species that form ectomycorrhizal associations (Taylor \& Alexander 2005). Ectomycorrhizal fungi can live without symbiotic association with host and are considered as facultative saprophytes. In the soil they compete for nutrient absorption and secrete variety of hydrolytic enzymes which are responsible for degradation of litter and complex organic compounds (Finlay 2008). Among the ectomycorrhizal fungi collected from the forest of $P$. gerardiana, the frequency of occurrence of $S$. polyrhizum was highest. It has been selected for artificial inoculations of $P$. gerardiana seedlings.

\section{Acknowledgements}

The authors are thankful to G.B. Pant National Institute of Himalayan Environment \& Sustainable Development, Almora for financial support (GBPI/IERP-NMHS/15-16/29/23) and to Dr. T.N. Lakhanpal for going through the manuscript. 


\section{References}

Agerer R. 1995 - Anatomical characteristics of identified ectomycorrhizas: An attempt towards a natural classification. In: Mycorrhiza. Varma, A. and Hock, B. (eds.). Springer Verlag, Berlin. pp. 685-734.

Bakshi BK, Thapar HS. 1960 - Mycorrhiza in Taxus baccata and Pinus wallichiana. Indian For. $86,16-17$.

Bakshi BK, Thaper HS. 1966 - Studies on mycorrhiza of chir pine (Pinus roxburghii) Proc. Nat. Inst. Sci. India, 32 B 6-20.

Brundrett MC. 2002 - Coevolution of roots and mycorrhizas of land plants. New Phytol. 154, 275304.

Bücking H, Liepold E, Ambilwade P. 2012 - The role of the mycorrhizal symbiosis in nutrient uptake of plants and the regulatory mechanisms underlying these transport processes. Plant Sci. 4, 108-132.

Chauhan J, Negi AK, Rajasekaran A, Pala NA. 2014 - Wild edible macro-fungi- A source of supplementary food in Kinnaur District, Himachal Pradesh, India. J. Med. Plants Stud. 2(1), 40-44.

Clasen BE, Silveira AO, Baldoni DB, Montagner DF et al. 2018 - Characterization of ectomycorrhizal species through molecular biology tools and morphotyping. Sci. Agr. 75(3), 246-254.

Crous PW. 2006 - How many species of fungi are there in tip of Africa? Stud. Mycol. 55, 13-33.

Finlay RD. 2008 - Ecological aspects of mycorrhizal symbiosis: with special emphasis on the functional diversity of interactions involving the extraradial mycelium. J. Exp. Bot. 59(5), $1115-1126$.

Hawksworth DL. 2004 - Fungal diversity and its implifications for genetic resource collections. Stud. Mycol. 50, 9-18.

Hawksworth DL, Sutton BC, Ainsworth GC. 1983 - Dictionary of the fungi. CMI, Kew Surrey England.

Jayasiri SC, Hyde KD, Ariyawansa HA, Bhat J, et al. 2015 - The Faces of Fungi database: fungal names linked with morphology, phylogeny and human impacts. Fungal Diversity 74(1):3-18 (DOI 10.1007/s13225-015-0351-8)

Johansen DA. 1940 - Plant microtechnique. Tata McGraw-Hill Publishing company, Bombay, New Delhi.

Kapoor KS, Kumar S, Singh O. 2003 - Chilgoza (Pinus gerardiana: Wall): Champion of the Rocky Mountains. HFRI Brochure, No. 8.

Kieliszewska-Rokicka B, Kurczynska EU, Leski T. 2000 - Physiological activity of ectomycorrhizas in a moderately polluted forest (Ratanica catchment, southern Poland). Dendrobiology 45, 47-59.

Kirk PM, Cannon PF, Minter DW, Stalpers JA. 2008 - Dictionary of the Fungi, $10^{\text {th }}$ Edition. CABI Publishing, Wallingford, UK.

Kumar A. 2010 - Studies on mycorrhizal relationships of Pinus gerardiana wall. and some mushroom species. Ph.D. thesis, Department of Biosciences, H.P. University, Shimla.

Kumar S. 1989 - Studies on Mycorrhiza of Picea smithiana and Pinus gerardiana. Ph. D. Thesis. H.P. Univ. Shimla.

Lakhanpal TN, Chaudhary S. 1988 - Studies on mycorrhiza of Pinus gerardiana. In: Mycorrhiza for Green Asia (Eds. Mahadevan, A., Ramman, M. and Natarajan, K.). Alamn Printing Works, Madras (Chennai). pp. 283-285.

Lakhanpal TN, Kumar S. 1984 - Studies on mycorrhiza and mycorrhizosphere of P. smithiana. J. Tree. Sci. 5, 122-125.

Malik AR, Shamet GS, Utola JS. 2012 - Natural regeneration status of Chilgoza pine (Pinus gerardiana Wall.) in Himachal Pradesh, India. Appl. Ecol. Environ. Res. 10(3), 365-373. 
Manoharachary C, Sridhar K, Singh R, Adholeya A et al. 2005 - Fungal biodiversity: distribution, conservation and prospecting of fungi from India. Curr. Sci. 89(1), 58-71.

Molina R, Massicotte H, Trappe JM. 1992 - Specificity phenomena in mycorrhizal symbiosis: Community ecological consequences and practical implications. In: Mycorrhizal Functioning, an integrative plant-fungal process. Allen, M.F. (ed.). Champman and Hall, New York. pp. $357-423$.

Parmar R. 2016 - Nutritional and biochemical investigations of some wild macrofungi of Himachal Pradesh. Ph.D. thesis, Shoolini University of Biotechnology and Management Sciences, Solan, Himachal Pradesh.

Peterson RL, Massicotte HB, Lewis H, Melville LH. 2004 - Mycorrhizas: Anatomy and cell biology. National Research Council, Ottawa, Canada.

Purakasthya RP, Chandra A. 1985 - Manual of Indian Edible Mushrooms. Today and Tomorrow's Publication, New Delhi.

Sehgal AK, Sagar A. 2017 - Ectomycorrhiza and fungal diversity in the mycorrhizosphere of Pinus gerardiana, Int. J. Pure App. Biosci. 5(1), 475-483.

Sehgal RN, Khosla PK. 1986 - Chilgoza pine the threatened social forestry tree of dry temperate Himalaya. National Symposium on Research in Social Forestry for Rural Development, January $1-2$.

Silva RF, Lupatini M, Trindade L, Antoniolli ZI et al. 2013 - Copper resistance of different ectomycorrhizal fungi such as Pisolithus microcarpus, Pisolithus sp., Scleroderma sp. and Suillus sp. Braz. J. Microbiol. 44, 619-627.

Singer R. 1986 - Agaricales in modern taxonomy, $4^{\text {th }}$ ed. Koeltz Scientific Books, Koenigstein.

Smith SE, Read D. 1997 - Structure and development of ectomycorrhizal roots. In: Mycorrhizal Symbiosis, $2^{\text {nd }}$ ed. Academic Press.

Taylor AFS, Alexander I. 2005 - The ectomycorrhizal symbiosis: Life in the real world. Mycologist, 19, 102-12.

Thakur NS, Gupta A, Chauhan VK. 2015 - Studies on quality characteristics of chilgoza nut and oil. Int. J. Farm Sci. 5(1), 78-82.

Van der Heijden MGA, Martin FM, Selosse MA, Sanders IR. 2015 - Mycorrhizal ecology and evolution: the past, the present, and the future. New Phytol. 205, 1406-1423.

Watkinson SC. 2016 - Mutualistic symbiosis between fungi and autotrophs. In: The Fungi, $3^{\text {rd }}$ ed.; Academic Press, Cambridge, MA, USA, pp. 205-243.

Zak B. 1971 - Characterization and identification of douglas fir mycorrhizae In: Mycorrhizae (Ed.: Hacskaylo, E.E.). Washington, D.C. pp. 38-53. 